\title{
Selenium concentrations in elderly people with Alzheimer's disease: a cross-sectional study with control group
}

\author{
Concentrações de selênio em idosos com doença de Alzheimer: um estudo transversal com grupocontrole
}

Concentraciones de selenio en ancianos con enfermedad de Alzheimer: un estudio trasversal con equipo-control

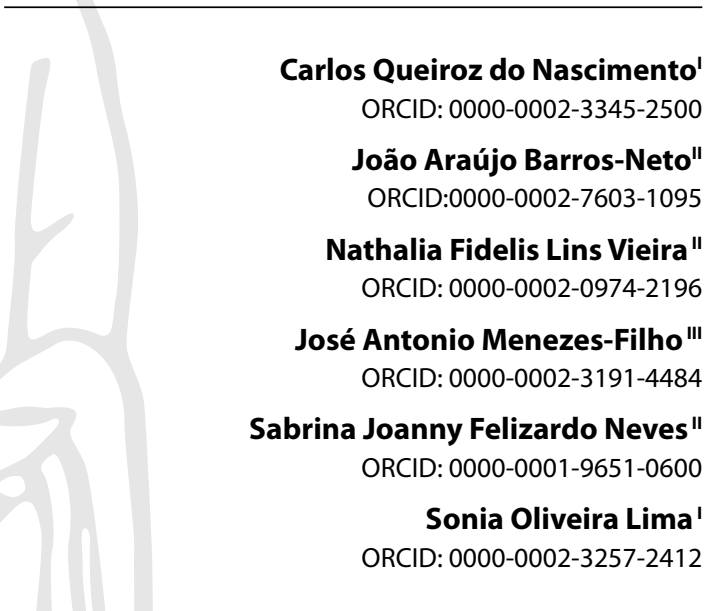

'Universidade Tiradentes. Aracaju, Sergipe, Brazil. "Universidade Federal de Alagoas. Maceió, Alagoas, Brazil. I"' Universidade Federal da Bahia. Salvador, Bahia, Brazil.

How to cite this article:

Nascimento CQ, Barros-Neto JA, Vieira NFL, Menezes-Filho JA, Neves SJF, Lima SO. Selenium concentrations in elderly people with Alzheimer's disease: a cross-sectional study with control group.

Rev Bras Enferm. 2021;74(Suppl 2):e20200984. https://doi.org/10.1590/0034-7167-2020-0984

Corresponding author:

Carlos Queiroz do Nascimento

E-mail: carlosqueiroz.nascimento@gmail.com

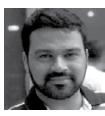

EDITOR IN CHIEF: Dulce Barbosa ASSOCIATE EDITOR: Alvaro Sousa

Submission: 05-30-2020

Approval: 09-26-2020

\section{ABSTRACT}

Objective: To investigate possible differences in plasma and erythrocyte concentrations of selenium among elderly with and without a diagnosis of Alzheimer's disease (AD). Methods: Cross-sectional study, performed with an elderly group with Alzheimer's disease, diagnosed by a geriatric doctor, and compared to an elderly group without the disease, equaling gender, education, and age. Atomic absorption spectrophotometry determined plasma and erythrocyte concentrations of total selenium ( $\mathrm{Se}_{\mathrm{t}}$ ). Results: The mean age was $74.41 \pm 7.1$ years in the Alzheimer's disease group and $71.46 \pm 5.1$ years among the control group. The Alzheimer's disease group presented lower plasma concentrations (mean of $45.29 \pm 14.51 \mu \mathrm{g} / \mathrm{dL}$ vs. $55.14 \pm 14.01 \mu \mathrm{g} / \mathrm{dL} ; \mathrm{p}=0.004$ ), and erythrocyte $\mathrm{Se}_{\mathrm{t}}$ (median of 56.36 $\mu \mathrm{g} / \mathrm{L}$ vs. $76.96 \mu \mathrm{g} / \mathrm{L} ; \mathrm{p}<0.001)$. The logistic regression model indicated an association between erythrocyte $\mathrm{Se}$, concentrations and diagnosis of Alzheimer's disease $(p=0.028)$. Conclusion Elderly with Alzheimer's disease present lower selenium concentrations in the evaluated organic compartments.

Descriptors: Selenium; Alzheimer's Disease; Elderly; Antioxidants; Dementia.

\section{RESUMO}

Objetivo: Investigar possíveis diferenças nas concentrações de selênio no plasma e nos eritrocitos de idosos com e sem a doença de Alzheimer (DA). Métodos: Estudo transversal, realizado com idosos com DA, diagnosticados por médico geriatra, e comparado a um grupo de idosos sem a doença, pareado por sexo, escolaridade e idade. As concentrações de selênio total $(\mathrm{Se})$ intraeritocitárias e plasmáticas foram determinadas por espectrofotometria de absorção atômica. Resultados: A média da idade foi $74,41 \pm 7,1$ anos no grupo DA e $71,46 \pm 5,1$ anos no grupo-controle. $O$ grupo doença de Alzheimer apresentou menores concentrações plasmáticas (média de $45,29 \pm 14,51 \mu \mathrm{g} / \mathrm{dL}$ vs. $55,14 \pm 4,01 \mu \mathrm{g} / \mathrm{dL} ; \mathrm{p}=0,004$ ) e eritrocitárias de $S e_{t}$ (mediana de $56,36 \mu \mathrm{g} / \mathrm{L}$ vs. $76,96 \mu \mathrm{g} / \mathrm{L} ; \mathrm{p}<0,001$ ). O modelo de regressão logística indicou associação entre concentrações eritrocitárias de $S e$, e o diagnóstico de doença de Alzheimer $(p=0,028)$. Conclusão: Idosos com DA apresentam concentrações menores de selênio plasmático e eritrocitário.

Descritores: Selênio; Doença de Alzheimer; Idoso; Antioxidantes; Demência.

\section{RESUMEN}

Objetivo: Investigar posibles diferencias en las concentraciones plasmáticas y eritrocitarias de selenio entre ancianos con y sin diagnóstico de Alzheimer (DA). Métodos: Estudio transversal, realizado con un equipo de ancianos con diagnóstico de Alzheimer, diagnosticados por geriatra, y comparado a un equipo de ancianos sin la enfermedad, pareado por sexo, escolaridad y edad. Las concentraciones plasmáticas y eritrocitarias de selenio total $\left(S_{t}\right)$ determinadas por espectrofotometría de absorción atómica. Resultados: La mediana de edad han sido $74,41 \pm 7,1$ años en el equipo diagnóstico de Alzheimer y $71,46 \pm 5,1$ años en el equipo-control. El equipo diagnóstico de Alzheimer presentó menores concentraciones plasmáticas (mediana de $45,29 \pm 14,51 \mu \mathrm{g} / \mathrm{dL}$ vs. $55,14 \pm 4,01 \mu \mathrm{g} / \mathrm{dL} ; \mathrm{p}=0,004$ ) y eritrocitarias de $S e_{t}$ (mediana de $56,36 \mu \mathrm{g} / \mathrm{L}$ vs. $76,96 \mu \mathrm{g} / \mathrm{L} ; \mathrm{p}<0,001$ ). El modelo de regresión logística indicó relación entre concentraciones eritrocitarias de $S e$ y el diagnóstico de diagnóstico de Alzheimer $(p=0,028)$. Conclusión: Ancianos con diagnóstico de Alzheimer presentan menores concentraciones de selenio en los compartimentos orgánicos evaluados. Descriptores: Selenio; Enfermedad de Alzheimer; Anciano; Antioxidantes; Demencia. 


\section{INTRODUCTION}

Population aging brings about problems that are a challenge to health systems ${ }^{(1-2)}$. Amongst those problems, dementias have caused older people's incapacity worldwide as they lead to a loss of independence and, almost inevitably, of autonomy ${ }^{(3-4)}$.

Alzheimer's disease (AD), the most common form of dementia, is characterized by the progressive impairment of memory and other functions, affecting occupational functioning. It has a prevalence of at least 27 million people worldwide, corresponding to between 60 and $70 \%$ of all dementia cases, with age being the leading risk factor for the disease ${ }^{(5)}$.

In addition to age, other factors may also favor the occurrence of damage to older people's central nervous system, amongst them oxidative stress, which seems to be related to the higher occurrence of lesions in brain regions responsible for cognition, which may lead to enzymatic inactivation, mutation, membrane rupture, and apoptosis ${ }^{(6)}$.

Oxidative stress plays a central role in the initiation and progression of $A D$. The brain is particularly vulnerable to oxidative damage due to its high oxygen consumption rate, high content of polyunsaturated lipids, which are susceptible to lipid peroxidation, and relatively low concentrations of antioxidants ${ }^{(7)}$. Furthermore, the aging process implies morphological and physiological changes in the brain, resulting in more significant reactive oxygen species (ROS) production and decreased antioxidant capacity ${ }^{(8)}$.

Currently, the available evidence suggests that a deficiency of nutrients with antioxidant activities such as vitamins $A$ and $E$, in addition to certain minerals such as zinc and selenium, is associated with cognitive decline, possibly due to some oxidative mechanism, in which antioxidants from the diet would act as protective factors against such diseases ${ }^{(9)}$.

Selenium is an important micronutrient in AD due to its multiple functions. As an antioxidant, it protects cellular damage mediated by oxidative stress through a series of selenoproteins, mainly glutathione peroxidase (GSH-Px) and selenoprotein $\mathrm{P}$, which prevent the formation of free radicals protecting the body from oxidative aggression ${ }^{(9-10)}$. Those proteins seem to be in lower concentrations in the different organic compartments (plasma, erythrocytes, cerebrospinal fluid, and brain tissues) of older people with cognitive decline compared to healthy older people ${ }^{(9,11-12)}$. Vincent et al. (2017) observed a positive correlation of the concentration of this nutrient's species in somebody compartments with the development of the disease ${ }^{(13)}$, a finding, which strengthens the need to clarify the association between selenium versus $A D$.

Despite the existence of meta-analysis, the results of available studies on plasma selenium levels in AD have proven inconsistent because while some studies reported $A D$ patients with lower levels of plasma selenium ${ }^{(7,14-15)}$, others have shown an increase or no change ${ }^{(16-17)}$. Erythrocyte concentrations evaluations, such as those performed in this study, are still insufficient but necessary to contribute to the understanding of homeostasis of this mineral in the elderly and its effects on $A D^{(9)}$.

Thus, knowing the organic concentrations of selenium, particularly in erythrocytes and plasma, is essential to better identify this nutrient's status in older people with AD since most studies are limited to analyzing the cerebrospinal fluid, serum, or brain tissues. Hence, there are very few studies that assist in understanding the nutritional status related to this mineral in older people, and the possible associations between the activity of this micronutrient in the process of development and progression of the disease, and may also contribute to the planning and management of health care actions for older people in the prevention or treatment of AD.

\section{OBJECTIVE}

To investigate if there were differences in plasma and erythrocyte concentrations of selenium between older people with and without a diagnosis of Alzheimer's disease.

\section{METHODS}

\section{Ethical aspects}

The study was developed following the recommendations of Resolution 466/2012 of the National Health Council of Brazil and approved by the Research Ethics Committee of the Federal University of Alagoas. The eligible patients and participants of the study signed, beforehand, the Free and Informed Consent Term.

\section{Design, period, and place of study}

This study is an exploratory and observational cross-sectional research with a control group, paired by gender, schooling, and age ( \pm 5 years).

The sample consisted of older people monitored at the Geriatric Outpatient Clinic of the University Hospital Prof. Alberto Antunes/ HUPAA and the Outpatient Nutrition Program for Elderly from the Nutrition College at the Federal University of Alagoas/UFAL from April 5, 2017, to July 30, 2018, and guided by the STROBE tool. (Strengthening the Reporting of Observational Studies in Epidemiology) ${ }^{(18)}$.

\section{Population or sample; criteria of inclusion and exclusion}

To calculate the sample size, it was determined mean values of plasma concentrations and standard deviations of selenium concentrations observed in a pilot project. These values were used to calculate the sample size.

The mean difference detected as significant was based on original published studies with Alzheimer's patients. This study's expected sample size was identified considering the significance level of $5 \%$ and power of $90 \%$. Thus, the sample size for comparison of the two proportions, i.e., the proportion of those exposed with the disease and those exposed with no disease, concerning the lower erythrocyte concentrations of total selenium, was 102 elderly, and considering the proportion of two controls per patient with a clinical diagnosis of Alzheimer's disease the sample size was 34 patients in the Alzheimer's disease group (AD) and 68 in the control group $(C)^{(19)}$.

The case group (AD) was formed by the elderly with a clinical diagnosis of Alzheimer's disease, all of whom met the study 
inclusion criteria $(n=34)$ and referred to this research by a geriatrician assessment and an AD diagnosis. The control group (C) composed of healthy elderly, preferably indicated by the patient or a caregiver (family members or people residing in the same geographic region), or by elderly already treated by the geriatrician, as long as they presented no criteria for AD, was assessed by the same professional, and met the pairing criteria, where two controls were recruited for each case $(n=68)$. It was also included elderly subjects of both gender and over 60 years old.

For the case group, the inclusion criteria were a diagnosis of Alzheimer's confirmed by a geriatric doctor, not using nutritional selenium supplementation, and not presenting with metabolic diseases recognized for compromising selenium metabolism. For the control group, it was used the same inclusion criteria as the case group, except for not being diagnosed with Alzheimer's and not presenting any cognitive impairment, also assessed by a geriatric doctor.

The study excluded elderly presenting physical disabilities and/or decompensated chronic diseases (heart disease, thyroid disease, chronic gastrointestinal disease, kidney disease, or liver failure), as well as elderly volunteers with cognitive impairment or other suspected types of dementia after geriatric assessment.

\section{Study protocol}

A previously established questionnaire was applied as a data collection tool during the first consultation, which contained information on lifestyle, anthropometric data, time since diagnosis and classification of Alzheimer's disease, and ethnic-racial characteristics (self-reported), sociodemographic variables, as well as plasma and erythrocyte selenium concentrations.

In the elderly group diagnosed with Alzheimer's disease, caregivers or family members helped them answer all the questions. In the control group, the elderly subjects answered the research questions themselves.

\section{Anthropometry}

The variable used in this study for nutritional diagnosis in the elderly was the Body Mass Index (BMI), calculated by the ratio between weight and the squared height. The weight of participants was obtained using a digital scale with a capacity of $200 \mathrm{~kg}$ and a precision of $50 \mathrm{~g}$, following the procedures established by Lohman, $1993^{(20)}$. Height was measured using a portable stadiometer (Seca ${ }^{\circledR}$, Hammer Steidamm - Hamburg, Germany), divided into tenths of centimeters, affixed to a flat surface according to methods proposed by Lohman, Roache and Martorell et al., $1992^{(21)}$. The classification of nutritional status by BMI followed the criteria of Lipschitz, 1994, which considers eutrophic BMI between 22 and $27 \mathrm{~kg} / \mathrm{m}^{2}$; malnutrition $\mathrm{BMI}<22$ $\mathrm{kg} / \mathrm{m}^{2}$ and overweight $\mathrm{BMI}>27 \mathrm{~kg} / \mathrm{m}^{2(22)}$.

\section{Diagnosis of Alzheimer's Disease (AD) and Cognitive ability}

A diagnosis of probable Alzheimer's disease was made by a geriatric doctor, based on the criteria of the National Institute of Neurological and Communicative Disorders and Stroke and the
Alzheimer's Disease and Related Disorders Association (NINCDS - ADRDA) ${ }^{(23)}$ and revised criteria from the National Institute on Aging-Alzheimer's Association ${ }^{(24)}$. The time of diagnosing the disease was considered from the first-listed diagnosis in the medical records.

Cognitive ability, in both groups, was assessed using the MiniMental State Examination (MMSE) ${ }^{(25)}$ on the first day of inclusion in this research.

\section{Blood collection and total selenium (Set) determination}

For total selenium (Set) determination, $18.0 \mathrm{~mL}$ of blood were collected, with participants fasting for at least 8 hours. Tubes with anticoagulant (sodium citrate $3.0 \%$ ) were used to obtain plasma. The blood was separated by centrifugation at 3,000 rpm for 15 minutes to obtain the plasma and transferred to eppendorf tubes with $1 \mathrm{~mL}$ capacity. After removing the plasma, the erythrocyte mass was obtained, washed with a $0.9 \%$ sodium chloride solution, and centrifuged at 10,000 rpm for 10 minutes (the procedure was repeated three times). The red cell mass was then extracted and stored at $-80^{\circ} \mathrm{C}$.

The plasma concentrations of $\mathrm{Se}_{\mathrm{t}}$ were determined by graphite furnace atomic absorption spectrophotometry, with Zeeman correction. The device's calibration conditions for selenium analysis were: Wavelength $(\lambda): 196.0 \mathrm{~nm}$; Lamp current: $290 \mathrm{~mA}$ and Slit: $2.0 \mathrm{~nm}$.

The Palladium ( $\mathrm{Pd})$ and $\mathrm{Mg}\left(\mathrm{NO}_{3}\right)_{2}$ were used as a matrix modifier $\left(200 \mu \mathrm{L}\right.$ of $\mathrm{Pd}$ and $125 \mu \mathrm{L}$ of $\mathrm{Mg}\left[\mathrm{NO}_{3}\right.$ ], diluted in $400 \mu \mathrm{L}$ of $\left.\mathrm{HNO}_{3} 0.2 \%\right)$. The method's detection limit was less than $10 \mu \mathrm{g} / \mathrm{L}$, precision (11\%) and imprecision (1\%). The samples were diluted in a $1: 4$ ratio with $\mathrm{HNO}_{3} 0.2 \%+$ TRITON $0.2 \%$. All samples were analyzed in duplicate.

The determination of the erythrocyte $\mathrm{Se}_{t}$ initially consisted of the digestion of the erythrocyte mass. For this, $2 \mathrm{~mL}$ of concentrated $\mathrm{HNO}_{3}$ and $500 \mu \mathrm{L}$ of $\mathrm{H}_{2} \mathrm{O}_{2}$ were added to the erythrocyte aliquots previously transferred to glass beakers. These vessels were kept at rest for 12 hours at room temperature, placed on a heating plate, which temperature was gradually increased from $50^{\circ} \mathrm{C}$ to $110^{\circ} \mathrm{C}$, over an average period of two hours. After the complete mineralization of the organic material, the solutions were brought to $5 \mathrm{~mL}$ with ultrapure water (Milli-Q, Merck/Millipore) and subjected to reading directly in the spectrometer GTA 120.

The cut-off point used to assess the plasma $\mathrm{Se}_{t}$ levels was $46-143 \mu \mathrm{g} / \mathrm{dL}$. As there is currently no consensus regarding the cut-off point for erythrocyte $\mathrm{Se}_{\mathrm{t}}$, the frequency of elderly with low intra-erythrocyte total selenium concentrations was analyzed by grouping the values encountered for the concentration of this trace element in the intracellular compartment, into quartiles. The results of the erythrocyte total selenium concentrations were expressed in $\mu \mathrm{g} / \mathrm{L}$.

\section{Analysis of results and statistics}

Statistical analyses considered the nature of the probability distribution and the behavior of the variables regarding their residues' normality was initially identified by applying the KolmogorovSmirnov test with Lilliefors correction. It was also considered, its 
classification and experimental design. Alpha value equal to $5 \%$ was adopted for rejection of the null hypothesis and the tests were processed using RStudio software - version 1.1.463 (2018).

The descriptive analysis of the data was performed to characterize and present the studied variables. The discrete / counting variables were presented in absolute ( $\mathrm{n}$ ) and relative (\%) frequencies, while the continuous variables were presented as measures of central tendency (mean or median) and dispersion / position (standard deviation or interquartile intervals).

The descriptive data analysis was performed to characterize and present the events studied. Absolute $(n)$ and relative (\%) frequencies were calculated for the discrete/score variables; and measures of central tendency (mean or median) and dispersion/ position [standard deviation (SD)or inter-quartile intervals (IQ)] were determined for the continuous variables.

The expected frequencies, and those observed, were compared using Pearson's Chi-Square test or Barnard's test. The magnitude of the association between exposure and outcome variables was assessed using the Odds Ratio (OR) and their respective $95 \% \mathrm{Cl}$. The potential exposure variables were selected to verify a possible association with the occurrence of Alzheimer's Disease, primarily through bivariate nonlinear analyses (logit) using a $\mathrm{p}$-value as the cutoff point for selection $p<0.2$.

To assess a possible significant difference $(p<0.05)$ for variables plasma and erythrocyte Se concentrations in the two groups outlined in the present study, it was adopted the t-Student and the Mann-Whitney test statistics, respectively.

To model the association of Alzheimer's disease according to the body's selenium reserves (serum and erythrocyte concentrations) and other possible confounding variables, it was adopted the GLM method (generalized linear models; "binomial" family), adjusting it according to the variables "gender", "age", and "schooling".

The best multiple linear regression model adopted to the referred study was the ordinary least squares (OLS) method in the "Backward" option. So, a model composed of explanatory variables for AD outcome was used until a better-adjusted model was obtained, respecting assumptions of normality of residues, homoscedasticity, and absence of multicollinearity, besides the quality of the alteration by the adjusted coefficient of determination $\left(R_{\text {adj }}{ }^{2}\right)$.

\section{RESULTS}

This research sample was formed by 102 elderly ( 34 with $A D$ and 68 no disease). Both groups were formed mostly by female subjects (64.7 and $77.9 \%$, respectively), married or in a stable relationship (70.6 and 50.8\%), non-smokers (97.1 and 98.5\%) (Table 1).

The mean age in the group of elderly people with Alzheimer's was 74.41 years $\pm 7.1 \mathrm{SD}$, and in the control group, 71.46 years $\pm 5.1 \mathrm{SD}$. The mean time of diagnosis of the disease in the AD group was approximately 11.4 months, and no older subject in this study presented a severe form of the disease. Fifteen (44.1\%) presented a mild state of AD and 19 (63.9\%) moderate.

The number of schooling years ( $<5$ years) associated with the presence of Alzheimer's disease, increasing approximately 3.2 times the chance of elderly people presenting $A D(x 2=7.09 ; p$ $=0.008)$ (Table 1$)$.

Table 1 - Socioeconomic profile, lifestyle, health conditions, nutritional status of elderly people with and without Alzheimer's Disease, Maceió, Alagoas, Brazil, 2018

\begin{tabular}{|c|c|c|c|c|c|c|c|c|}
\hline & \multicolumn{2}{|c|}{$\begin{array}{c}A D \\
(n=34)\end{array}$} & \multicolumn{2}{|c|}{$\begin{array}{c}C \\
(n=68)\end{array}$} & \multirow[t]{2}{*}{$x^{2}$} & \multirow{2}{*}{$p$ value } & \multirow[t]{2}{*}{ OR } & \multirow{2}{*}{$\underset{\left(I C_{95 \%}\right)}{\text { OR }}$} \\
\hline & $\mathbf{N}$ & $\%$ & $\mathbf{n}$ & $\%$ & & & & \\
\hline \multicolumn{9}{|l|}{ Gender } \\
\hline Male & 12 & 35.3 & 15 & 22.1 & \multirow[t]{2}{*}{2.04} & $0.153^{\mathrm{a}}$ & \multirow{2}{*}{0.51} & \multirow[t]{2}{*}{$0.290-0.1286$} \\
\hline Female & 22 & 64.7 & 53 & 77.9 & & & & \\
\hline \multicolumn{9}{|l|}{ Equivalent Income } \\
\hline$>1 \mathrm{MW}$ & 24 & 70.6 & 39 & 57.3 & \multirow[t]{2}{*}{1.68} & $0.195^{\mathrm{a}}$ & \multirow{2}{*}{0.56} & \multirow[t]{2}{*}{$0.232-1.286$} \\
\hline$<1 \mathrm{MW}$ & 10 & 29.4 & 29 & 42.7 & & & & \\
\hline \multicolumn{9}{|l|}{ Schooling } \\
\hline$>5$ years of study & 10 & 29.4 & 39 & 57.4 & \multirow[t]{2}{*}{7.09} & $0.008^{\mathrm{a}}$ & \multirow{2}{*}{3.23} & \multirow[t]{2}{*}{$1.338-7.785$} \\
\hline$<5$ years of study & 24 & 70.6 & 29 & 42.6 & & & & \\
\hline \multicolumn{9}{|l|}{ Marital Status } \\
\hline Married/stable relationship & 24 & 70.6 & 40 & 58.8 & \multirow{2}{*}{1.34} & $0.247^{\mathrm{a}}$ & \multirow{2}{*}{0.59} & \multirow{2}{*}{$0.246-1.438$} \\
\hline Single/divorced/ widowed & 10 & 29.4 & 28 & 41.2 & & & & \\
\hline \multicolumn{9}{|l|}{ Hypertension } \\
\hline Yes & 20 & 58.8 & 42 & 61.8 & \multirow[t]{2}{*}{0.08} & $0.774^{\mathrm{a}}$ & \multirow[t]{2}{*}{0.88} & \multirow[t]{2}{*}{$0.382-2.049$} \\
\hline No & 14 & 41.2 & 26 & 38.2 & & & & \\
\hline \multicolumn{9}{|l|}{ Diabetes } \\
\hline Yes & 9 & 26.5 & 10 & 14.7 & \multirow[t]{2}{*}{2.07} & $0.150^{\mathrm{a}}$ & \multirow[t]{2}{*}{2.09} & \multirow[t]{2}{*}{$0.756-5.763$} \\
\hline No & 25 & 73.5 & 58 & 85.3 & & & & \\
\hline \multicolumn{9}{|l|}{ Bone diseases } \\
\hline Yes & 1 & 2.9 & 16 & 23.5 & \multirow[t]{2}{*}{2.63} & $0.020^{b}$ & 0.10 & $0.012-0.778$ \\
\hline No & 33 & 97.1 & 52 & 76.5 & & & & \\
\hline Nutritional status & & & & & & & & \\
\hline Malnutrition & 3 & 8.8 & 4 & 5.9 & -0.55 & $0.625^{\mathrm{b}}$ & 1.10 & $0.683-0.429$ \\
\hline Eutrophic/Overweight & 31 & 81.2 & 64 & 94.1 & & & & \\
\hline
\end{tabular}

Notes: $A D=$ Alzheimer's disease (case group) $C \mathrm{C}=$ control group; $M W=$ Minimum wage - equivalent to $R \$$ 937,00/month, approx $\cdot{ }^{a}$ Pearson 's chi-squared test; ${ }^{b}$ Barnard Unconditional test. 
It may be stated that, concerning health conditions and nutritional status, the groups were similar, with no significant difference in the frequencies of older people with hypertension, diabetes, or malnutrition. However, there was a higher frequency of reports of bone diseases (osteopenia/osteoporosis) in the group of elderly people with Alzheimer's ( $2=0,020 ; p=0,010$ ) (Table 1).

It was observed that the group of elderly people with Alzheimer's presented lower concentrations of plasma $\mathrm{Se}_{t} 45.29 \mu \mathrm{g} / \mathrm{dL} \pm 14.51$ SD vs. 55.14 $\mu \mathrm{g} / \mathrm{dL} \pm 14.01 \mathrm{SD}(\mathrm{p}=0.004)$. Lower erythrocyte concentrations of $\mathrm{Se}_{t}$ were also observed in the group of elderly people diagnosed with AD (Median = 56.36 $\mu \mathrm{g} / \mathrm{L} ;$ Minimum $=40.64 \mu \mathrm{g} / \mathrm{L}$; Maximum $=93.99 \mu \mathrm{g} / \mathrm{L}$ vs. Median $=76.96 \mu \mathrm{g} / \mathrm{L} ;$ Minimum $=26.33$ $\mu \mathrm{g} / \mathrm{L}$; Maximum $=141.04 \mu \mathrm{g} / \mathrm{L})(\mathrm{p}<0.001)$ (Figure 1).

The frequency of elderly people classified as presenting low plasma $\mathrm{Se}_{\mathrm{t}}$ concentrations was higher in the case group $(60.60 \%$ vs. $27.69 \% ; x^{2}=8.48 ; p=0.004$ ). Similarly, the frequency of elderly people grouped in the $1^{\text {st }}$ quartile for erythrocyte $\mathrm{Se}_{t}$ concentrations was higher in the group of elderly people with Alzheimer's (51.51\% vs. $\left.11.29 \% ; x^{2}=13.34 ; p<0.001\right)$.
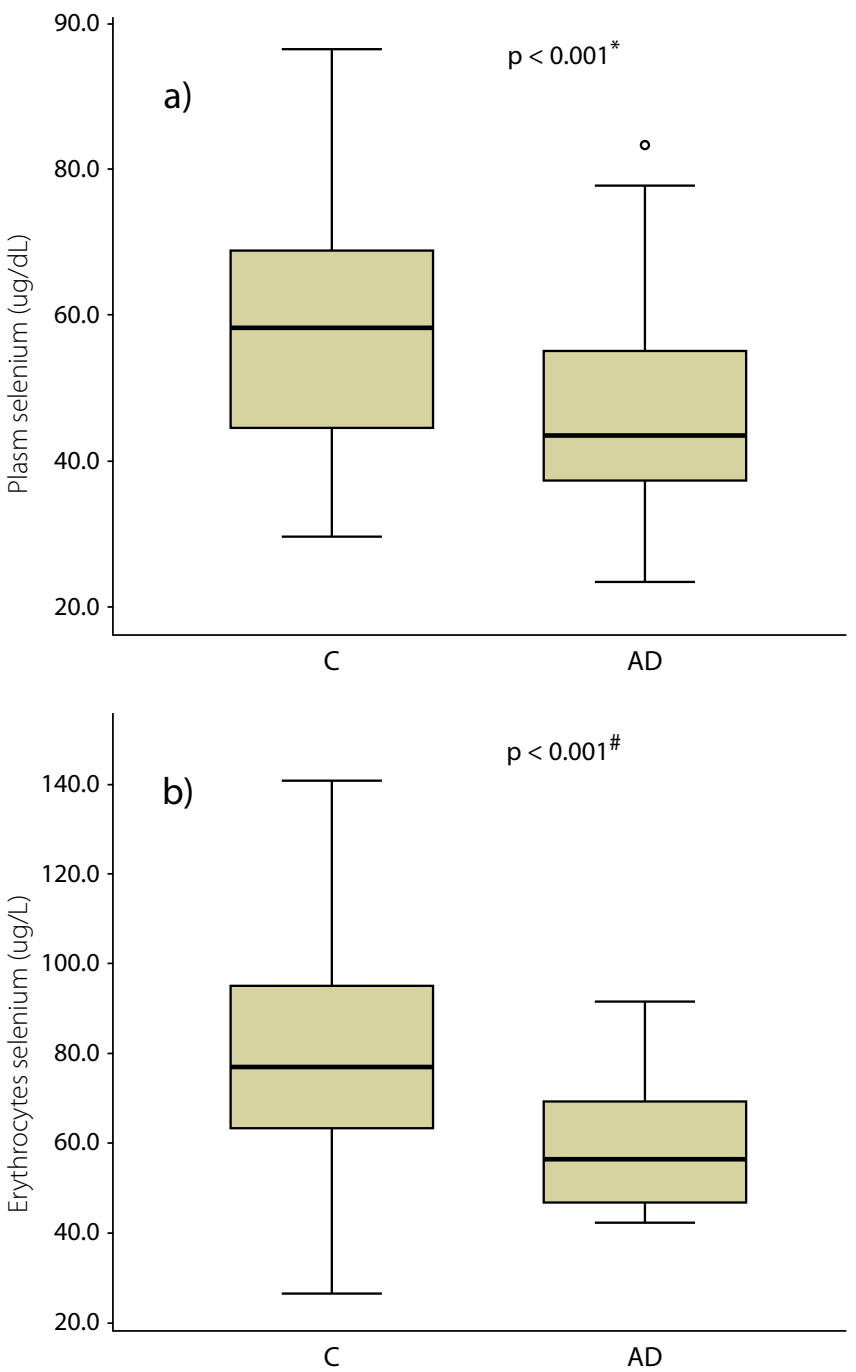

Legend: a) Plasma selenium concentration in elderly people with and without Alzheimer's; b) Erythrocyte selenium concentration in older people with and without Alzheimer's; ${ }^{*} t$-Student test; \# Mann-Whitney test.

Figure 1 - Plasma and Erythrocyte selenium concentration in elderly people with and without Alzheimer's, Maceió, Alagoas, Brazil, 2018
The plasma and erythrocyte $\mathrm{Se}_{\mathrm{t}}$ concentrations showed no association with the time of diagnosis of the disease in the case group ( $p>0.050)$.

The mean score obtained in the MMSE by the elderly people in the case group was 18 points (Min. $=16$ and Max. $=20$ points), while the mean in the control group was 26 points (Min. $=24$ and Max $=28$ points).

When considering that the score obtained in the MMSE, in each group, presented with its residues distributed in a standard curve of probabilities, a linear regression analysis was performed to explain the effect of the plasma and erythrocyte concentrations of Set in reducing the cognitive capacity assessed by the MMSE, adjusted for schooling, age, and gender. Plasma $\mathrm{Se}_{\mathrm{t}}$ concentration did not correlate with the cognitive ability of the elderly people. However, the intra-erythrocyte $\mathrm{Se}_{\mathrm{t}}$ concentration demonstrated a positive correlation with the cognitive capacity assessed by the mini-mental state exam in both groups and all models (Table 2).

Table 2 - Linear regression coefficients for cognitive ability assessed by the Mini-Mental State Examination (MMSE) screening instrument in the elderly with and without Alzheimer's disease (AD), Maceió, Alagoas, Brazil, 2018

\begin{tabular}{|c|c|c|c|c|c|c|}
\hline & \multicolumn{2}{|c|}{ Model 1} & \multicolumn{2}{|c|}{ Model 2} & \multicolumn{2}{|c|}{ Model 3} \\
\hline & $\beta^{a}$ & $p$ value $^{b}$ & $\beta^{a}$ & $p$ value $^{b}$ & $\beta^{a}$ & $p$ value \\
\hline \multicolumn{7}{|l|}{ Group AD $(n=34)$} \\
\hline $\mathrm{Se}_{t}$ plasma & 0.146 & 0.250 & 0.068 & 0.647 & - & - \\
\hline Se erythrocytes & 0.513 & $<0.001$ & 0.502 & 0.002 & 0.508 & 0.002 \\
\hline Schooling & -0.087 & 0.491 & 0.002 & 0.990 & -0.007 & 0.962 \\
\hline Age & -0.284 & 0.033 & -0.270 & 0.084 & -0.284 & 0.060 \\
\hline Gender & -0.446 & 0.001 & - & - & - & - \\
\hline$R^{2}$ & \multicolumn{2}{|c|}{0.609} & \multicolumn{2}{|c|}{0.426} & \multicolumn{2}{|c|}{0.422} \\
\hline Adjusted $\mathrm{R}^{2}$ & \multicolumn{2}{|c|}{0.540} & \multicolumn{2}{|c|}{0.347} & \multicolumn{2}{|c|}{0.364} \\
\hline \multicolumn{7}{|l|}{ Group C $(n=68)$} \\
\hline Se plasma & 0.104 & 0.414 & 0.113 & 0.370 & - & - \\
\hline Se,erythrocytes & 0.429 & $<0.001$ & 0.519 & $<0.001$ & 0.570 & $<0.001$ \\
\hline Schooling & 0.025 & 0.825 & 0.016 & 0.887 & -0.003 & 0.976 \\
\hline Age & -0.086 & 0.446 & -0.072 & 0.513 & -0.048 & 0.651 \\
\hline Gender & -0.076 & 0.493 & - & - & - & - \\
\hline & \multicolumn{2}{|c|}{0.335} & \multicolumn{2}{|c|}{0.330} & \multicolumn{2}{|l|}{0.321} \\
\hline Adjusted $\mathrm{R}^{2}$ & \multicolumn{2}{|c|}{0.281} & \multicolumn{2}{|c|}{0.287} & 0.289 & \\
\hline
\end{tabular}

Notes: $A D=$ Alzheimer's disease (case group); $C=$ control group; Regression coefficients (Beta) estimated by the MQO/Backward option ${ }^{a} ;{ }^{b}$ Test $t ; p<0.05 ;$ Model 1: Adjusted for schooling, age, and gender; Model 2: Adjusted for schooling and age; Model 3: Adjusted for schooling, age, and gender, but excluding Se, plasma from this model.

The logistic regression model, adjusted for schooling, age, and gender, was proposed to identify the association of this study's findings with Alzheimer's disease. The initial model included the plasma and erythrocyte concentrations of $\mathrm{Se}_{\mathrm{t}^{\prime}}$ clinical diagnosis of hypertension and diabetes, nutritional status, physical activity, housing conditions, and income.

After excluding $\mathrm{Se}_{\mathrm{t}}$ plasma, a clinical diagnosis of hypertension, and diabetes, physical activity, nutritional status, housing conditions and income, only the concentration of intra-erythrocyte $\mathrm{Se}_{t}$ demonstrated a significant association with AD. With a 95\% confidence, it was observed that for each $1 \mu \mathrm{g} / \mathrm{L}$ increase of intracellular $\mathrm{Se}_{t}$ there was a reduction of approximately $2.5 \%$ in the chance of older people having $\mathrm{AD}(\mathrm{OR}=0.975 ; \mathrm{p}=0.028 ; 95 \% \mathrm{Cl}=0.953-0.997)$.

\section{DISCUSSION}

In the present study, the plasma and erythrocyte concentrations of Se ${ }^{t}$ appear as significant risk factors for Alzheimer's disease and 
cognitive ability. However, the erythrocyte concentrations of selenium $\left(\mathrm{Se}_{\mathrm{t}}\right)$, when adjusted for age, gender, and schooling, show an independent predictor for the disease. Study time and age, factors are already known in the literature to increase the risk for $A D$ development, were also risk factors observed in this research. It is important to note that it was not observed a correlation between age and selenium concentrations.

The number of academic years in the group of elderly people with Alzheimer's was shorter than the group with no disease. A study by Iwata et al., 2019, identified a possible association between schooling and mild cognitive impairment, where the highly educated men showed a significantly slower rate of decline than the other groups ${ }^{(26)}$. A meta-analysis of prospective cohort studies investigated the relationship between schooling and risk of dementia and found that lower schooling achievement is related to a higher incidence of dementia, and risk decreases with each year increase in schooling ${ }^{(27)}$.

The present study identified that the group of elderly people with AD presented lower concentrations of plasma and erythrocyte $\mathrm{Se}_{\mathrm{t}}$. However, Ceballos-Picot et al., 1996, observed an inverse association between cognitive decline and selenium concentrations, where a group of elderly people with AD presented higher selenium concentrations in erythrocytes and plasma ${ }^{(28)}$.

A case-control study carried out by Cardoso et al., 2014, in São Paulo - Brazil, observed that the lowest plasma and erythrocyte selenium concentrations were in the group of elderly people with $A D$ when compared to the control group ${ }^{(14)}$. Likewise, a study by Chmatalova et al., 2017, in the Czech Republic also reported lower concentrations of plasma selenium in people with Alzheimer's when compared to the control group ${ }^{(7)}$, thereby corroborating the results obtained in the present study.

It should be noted that the criteria used by the researchers in the first study were less sensitive for Alzheimer's (and more sensitive for other dementias), and the analysis of plasma selenium was performed by fluorometry, differing from most studies that, as in the present case, used atomic absorption spectrophotometry.

A recent systematic review with a meta-analysis observed that circulating levels of selenium (serum, plasma, or whole blood) are lower in the group of elderly people with Alzheimer's. This result was also observed for erythrocyte concentrations, but with no statistical relevance, due to significant heterogeneity between the two studies involved in this meta-analysis $\left(\mathrm{I}^{2}=\right.$ $81 \%)^{(9)}$. The present study corroborates the observed results and suggests that further studies should be conducted, especially with analysis of erythrocyte selenium, to elucidate the relationship between selenium and AD better.

Considering that oxidative stress is the first event that precedes $A D$ and, therefore, assumes an important role in the disease's etiology, low concentrations of this micro-element may be associated with its depletion due to the oxidation that accompanies aging and the progression of $A D^{(10,29-30)}$.

The balance between oxidizing and antioxidant mechanisms often carried out by this micronutrient may be a factor that assists in the discovery of some responses ${ }^{(31)}$. However, in this study, it was not possible to assess oxidative stress in patients.
Moreover, the lower concentrations of plasma selenium found in the group of older people with AD may be secondary to an insufficient current intake of this mineral. However, this matrix's selenium levels may be affected by factors other than impaired food intake, particularly in the acute phase of the inflammatory response and oxidative stress ${ }^{(32-33)}$. It should be highlighted that erythrocytes are the primary locus of storage of this mineral in the human body and the reduction of its concentrations occurs more slowly than in plasma due to the relatively long life of the erythrocytes ${ }^{(32)}$. That reinforces the hypothesis that low levels of intra-erythrocyte selenium, as observed in this study, may reflect the chronic impairment of this mineral intake or increased metabolic demand over the years, contributing to the development or clinical evolution of the disease.

This study's design, which is cross-sectional with a comparison group, does not enable the identification of the close causeeffect relationship between low concentrations of selenium and the onset of Alzheimer's disease. However, it does evidence the relationship between the two clinical conditions. Finally, it emphasizes that given the above, there is a need to obtain a better clarification of the relationship between selenium deficiency and $A D$ to establish effective therapeutic measures subsequently. That may be achieved either by correcting the usual food intake, supplementation, developing new drugs, or even by combining these actions with stimulating the development of occupational activities that are known to reduce the risk for the disease and guarantee the quality of life during the aging process since studies on selenium supplementation (alone or combined with other nutrients) as the only therapy used in the treatment of $A D$ are also imprecise and have presented contradictory results ${ }^{(34-38)}$.

Since few studies have assessed erythrocyte concentrations in elderly people with Alzheimer's, we suggest that further epidemiological and clinical character studies should clarify the causal relationship between low selenium concentrations and AD. Clinically, it is necessary to assess the effects of supplementation in an uninterrupted manner and, in the long term, added to other potential factors for the treatment, thereby enabling us to properly understand the role of this nutrient in preventing and/or controlling the progression of $\mathrm{AD}$. It is also a suggestion to include a more significant number of patients diagnosed with $A D$ in study groups for future research.

\section{Study limitations}

In this study, it was impossible to establish a direct association between selenium deficiency and oxidative stress in patients with $A D$, which is a significant limitation of this study. Nonetheless, a hypothesis of an indirect relationship seems to be established.

Another critical limitation concerns the assessment of cognitive capacity assessed by the MMSE. Although the Mini-Mental State Examination is a valid and internationally accepted method for identifying cognitive impairment, this assessment is affected by other variables' strong influences (such as emotional state, motivation for treatment, and schooling). However, that limitation was rectified by adjusting the analysis by schooling to avoid bias in interpreting the results. 


\section{Contributions to the fields of Nursing, Health, or Public Policy}

This study aimed to contribute to the establishment of effective therapeutic measures, by correcting the usual food intake, by supplementation or developing new drugs or even by combining these actions through the stimulation of occupational activities which, as it is known, reduce the risk for disease and guarantee the quality of life in the aging process. Nevertheless, it is essential to highlight that new pharmacotherapy should not limit treatment nor follow one postulated hypothesis. There is a need to consider disease prevention through health care strategies.

\section{CONCLUSION}

The results of this research suggest that plasma and erythrocyte concentrations of total selenium ( $\mathrm{Se}_{\mathrm{t}}$ ) have an important association with Alzheimer's disease and that erythrocyte concentrations may increase the chances of elderly people being diagnosed with AD.

\section{ACKNOWLEDGMENT}

We would like to thank the nutritionist Thainá Barbosa Wanderley for her contribution to the data collection of this research. We would also like to thank the technicians of the Toxicology Laboratory (LabTox) of the Federal University of Bahia for their assistance in the analysis of biological material.

\section{FUNDING}

This research was financed by the Fundação de Amparo a Pesquisa de Alagoas in partnership with the State Health Secretariat of Alagoas and the Brazilian Ministry of Health with resources for Research for the Integrated Health System and by the Coordenação de Aperfeiçoamento de Pessoal de Nível Superior - Brasil (CAPES) with funding for a master's scholarship that enabled the development of the research and dissertation ${ }^{(39)}$ that resulted from this manuscript.

\section{REFERENCES}

1. Partridge L, Deelen J, Slagboom PE. Facing up to the global challenges of ageing. Nature. 2018;561:45-56. https://doi.org/10.1038/ s41586-018-0457-8

2. Wang S, Yang S, Jia W, Cao W, Han K, Liu M, et al. Relationships of lipids profile with health-related quality of life in Chinese Centenarians. J Nutr Health Aging. 2020;24:404-11. https://doi.org/10.1007/s12603-020-1340-5.

3. Hartman YAW, Karssemeijer EGA, Van Diepen LAM, Olde Rikkert MGM, Thijssen DHJ. Dementia patients are more sedentary and less physically active than age- and sex-matched cognitively healthy older adults. Dement Geriatr Cogn Disord. 2018;46(1-2):81-9. https://doi. org/10.1159/000491995

4. Mc Ardle R, Del Din S, Donaghy P, Galna B, Thomas A, Rochester L. Factors that influence habitual activity in mild cognitive impairment and dementia. Gerontol. 2020;66(2):197-208. https://doi.org/10.1159/000502288

5. Silva MVF, Loures CDMG, Alves LCV, Souza LC, Borges KBG, Carvalho MDG. Alzheimer's disease: risk factors and potentially protective measures. J Biomed Sci. 2019;9;26(1):3. https://doi.org/10.1186/s12929-019-0524-y

6. Cosín-Tomàs $M$, Senserrich J, Arumí-Planas $M$, Alquézar $C$, Pallàs $M$, Martín-Requero Á, et al. Role of resveratrol and selenium on oxidative stress and expression of antioxidant and anti-aging genes in immortalized lymphocytes from Alzheimer's Disease Patients. Nutrients. 2019;11(8):1764. https://doi.org/10.3390/nu11081764

7. Chmatalova Z, Vyhnalek M, Laczo J, Hort J, Pospisilova R, Pechova M, et al. Relation of plasma selenium and lipid peroxidation end products in patients with Alzheimer's Disease. Physiol Res. 2017;20;66(6):1049-56. https://doi.org/10.33549/physiolres.933601

8. Cardoso RB, Cominetti C, Cozzolino SMF. Importance and management of micronutrient deficiencies in patients with Alzheimer's disease. Clin Interv Aging. 2013;8:531-42. https://doi.org/10.2147/CIA.S279883

9. Reddy VS, Bukke S, Dutt N, Rana P, Pandey AK. A systematic review and meta-analysis of the circulatory, erythrocellular and CSF selenium levels in Alzheimer's disease: a metal meta-analysis (AMMA study-I). J Trace Elem Med Biol. 2017;42:68-75. https://doi.org/10.1016/j. jtemb.2017.04.005

10. Solovyev N, Drobyshev E, Bjørklund G, Dubrovskii Y, Lysiuk R, Rayman MP. Selenium, selenoprotein P, and Alzheimer's disease: is there a link? Free Radic Biol Med. 2018;127:124-33. https://doi.org/10.1016/j.freeradbiomed.2018.02.030

11. Varikasuvu SR, Prasad VS, Kothapalli J. Manne M. Brain Selenium in Alzheimer's Disease (BRAIN SEAD Study): a systematic review and metaanalysis. Biol Trace Elem Res. 2019;189:361-9. https://doi.org/10.1007/s12011-018-1492-x

12. Wilde MC, Vellas B, Girault E, Yavuz AC, Sijben JW. Lower brain and blood nutrient status in Alzheimer's disease: results from meta-analyses. Alzheimer's Dement. 2017;416-31. https://doi.org/10.1016/j.trci.2017.06.002

13. Vinceti M, Chiari A, Eichmüller M, Rothman KJ, Filippini T, Malagoli C, et al. A selenium species in cerebrospinal fluid predicts conversion to Alzheimer's dementia in persons with mild cognitive impairment. Alzheimers Res Ther. 2017;9(1):100. https://doi.org/10.1186/s13195-017-0323-1

14. Cardoso BR, Bandeira VS, Jacob-Filho W, Silvia MFC. Selenium status in elderly: relation to cognitive decline. J Trace Elem Med Biol. 2014;28(4):422-6. https://doi.org/10.1016/j.jtemb.2014.08.009

15. Gerhardsson L, Lundh T, Minthon L, Londos E. Metal concentrations in plasma and cerebrospinal fluid in patients with Alzheimer's disease. Dement Geriatr Cogn Disord. 2008;25(6):508-15. https://doi.org/10.1159/000129365 
16. Paglia G, Miedico O, Cristofano A, Vitale M, Angiolillo A, Chiaravalle AE, et al. Distinctive pattern of serum elements during the progression of Alzheimer's Disease. Sci Rep. 2016;9;6:22769. https://doi.org/10.1038/srep22769

17. Koç ER, Illhan A, Aytürk Z, Illhan A, Acar B. A comparison of hair and serum trace elements in patients with Alzheimer disease and healthy participants. Turk J Med Sci. 2015;45(5):1034-9. https://doi.org/10.3906/sag-1407-67

18. Elm EV, Altman DG, Egger M, Pocock SJ, Gøtzsche PC, Vandenbroucke JP, et al. The Strengthening the Reporting of Observational Studies in Epidemiology (STROBE) statement: guidelines for reporting observational studies. J Clin Epidemiol. 2008;61:344-9. https://doi.org/10.1016/j. jclinepi.2007.11.008

19. Lwanga SK, Lemeshow S. Sample size determination in health studies: a practical manual [Internet]. Geneva, Suiça: World Health Organization; 1991 [cited 2020 Apr 20]. 80 p. Available from: https://apps.who.int/iris/handle/10665/40062

20. Lohman TG. Advances in body composition assessment. Med Sci Spots Exerc. 1993;25:762. https://doi.org/10.1590/ S0102-311X1993000500016

21. Lohman TJ, Roache AF, Martorell R. Anthropometric standardization reference manual. Med Sci Spots Exerc. 1992;24:952. https://doi. org/101249/00005768-199208000-00020

22. Lipschitz DA. Screening for nutritional status in the elderly. Prim Care. 1994;2(1)1:55-7.

23. Mckhann GM, Knopman DS, Chertkow H, Hyman BT, Jack CR Jr, Kawas CH, et al. The diagnosis of dementia due to Alzheimer's disease: recommendations from National Institute on Aging and the Alzheimer's Association workgroup. Alzheimer's Dement. 2011;7(3):263-9. https://doi.org/10.1016/j.jalz.2011.03.005

24. Jack Jr CR, Albert MS, Knopman DS, McKhann GM, Sperling RA, Carrillo MC, et al. Introduction to the recommendations from the National Institute on Aging-Alzheimer's Association workgroups on diagnostic guidelines for Alzheimer's disease. Alzheimers Dement. 2011;7:257e62. https://doi.org/10.1016/j.jalz.2011.03.004

25. Kochham R, Varela JS, Lisboa CS, Chaves MLF. The mini mental state examination: review of cutoff ponits adjusted for schooling in a large southern Brazilian sample. Dement Neuropsychol. 2010;4(1):35-41. https://doi.org/10.1590/S198

26. Iwata A, Iwatsubo T, Ihara R, Suzuki K, Matsuyama Y, Tomita N, et al. Effects of sex, educational background, and chronic kidney disease grading on longitudinal cognitive and functional decline in patients in the Japanese Alzheimer's Disease Neuroimaging Initiative study. Alzheimers Dement. 2018;4:765-74. https://doi.org/10.1016/j.trci.2018.06.008

27. Xu W, Tan L, Wang HF, Tan MS, Tan L, Li JQ, et al. Education and risk of dementia: dose-response meta-analysis of prospective cohort studies. Mol Neurobiol. 2016;53:3113-23. https://doi.org/10.1007/s12035-015-9211-5

28. Ceballos-Picot I, Merad-Boudia M, Nicole A, Thevenin M, Hellier G, Legrain S, et al. Peripheral antioxi $\neg$ dant enzyme activities and selenium in elderly subjects and in dementia of Alzheimer's type - place of the extracellular glutathione peroxidase. Free Radic Biol Med. 1996;20(4):579-87. https://doi.org/10.1016/0891-5849(95)02058-6

29. Luchsinger JA, Mayeux R. Dietary factors and Alzheimer's disease. Lancet Neurol. 2004;3(10):579-87. https://doi.org/10.1016/S1474-4422(04)00878-6

30. Zhu X, Lee H, Perry G, Smith MA. Alzheimer disease, the two-hit hypothesis: an update. Biochim Biophys Acta. 2007;1772(4):494-502. https:// doi.org/10.1016/S1474-4422(04)00878-6

31. Aaseth J, Alexander J, Bjørklund G, Hestad K, Dusek P, Roos PM, et al. Treatment strategies in Alzheimer's disease: a review with focus on selenium supplementation. Biometals. 2016;29(5):827-39. https://doi.org/10.1007/s10534-016-9959-8

32. Stefanowicz FA, Alwar D, O'Reilly DSJ, Dickinson N, Atkinson J, Hursthouse AS, et al. Erythrocyte selenium concentration as a marker of selenium status. Am J Clin Nutr. 2020; 32 (5)837-42. https://doi.org/10.1093/ajcn/nqaa095

33. Duncan A, Talwar D, McMillan DC, Stefanowicz F, O'Reilly DSJ. Quantitative data on the magnitude of the systemic inflammatory response and its effect on micronutrient status based on plasma measurements. Am J Clin Nutr. 2012;95(1):64e71. https://doi.org/10.3945/ajcn.111.023812

34. Cornelli U. Treatment of Alzheimer's Disease with a Cholinesterase Inhibitor Combined with Antioxidants. Neurodegenerative Dis. 2010;7,193-202. https://doi.org//10.1159/000295663

35. Onakpoya IJ, Heneghan CJ. The efficacy of supplementation with the novel medical food, Souvenaid, in patients with Alzheimer's disease: a systematic review and meta-analysis of randomized clinical trials. Nutr Neurosci. 2017;20(4):219-27. https://doi.org/10.1080/102841 $5 X .2015 .1110899$

36. Kryscio RJ, Abner EL, Caban-Holt A, Lovell M, Goodman P, Dark AK, et al. Association of antioxidant supplement use and Dementia in the Prevention of Alzheimer's Disease by Vitamin E and Selenium Trial (PREADViSE). JAMA Neurol. 2017;74(5):567-73. https://doi.org/10.1001/ jamaneurol.2016.5778

37. Van der Jeugd A, Parra-Damas A, Baeta-Corral R, Soto-Faguás CM, Ahmed T, LaFerla FM, et al. Reversal of memory and neuropsychiatric symptoms and reduced tau pathology by selenium in 3xTg-AD mice. Sci Rep. 2018;8(1):6431. https://doi.org/10.1038/s41598-018-24741-0

38. Tamtaji OR, Heidari-Soureshjani R, Mirhosseini N, Kouchaki E, Bahmani F, Aghadavod E, et al. Probiotic and selenium co-supplementation, and the effects on clinical, metabolic and genetic status in Alzheimer's disease: a randomized, double-blind, controlled trial. Clin Nutr. 2019;38(6):2569-75. https://doi.org/10.1016/j.clnu.2018.11.034

39. Nascimento CQ. Níveis plasmáticos e eritrocitários de selênio em idosos com Alzheimer: um estudo caso-controle [Dissertação] [Internet]. Maceió: Universidade Federal de Alagoas - UFAL; 2019[cited 2020 Apr 20]. http://www.repositorio.ufal.br/handle/riufal/5581 